\title{
Epidemiology of Sepsis in Neonates: Microbiological Profile and Antibiotic Susceptibility
}

\section{Yenidoğan Sepsis Epidemiyolojisi: Etken Dağılımı ve Antibiyotik Duyarlııkları}

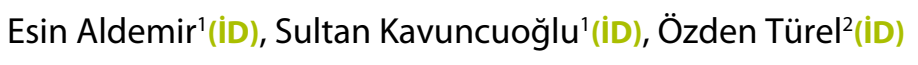 \\ ${ }^{1}$ Clinic of Pediatrics, Health Sciences University, Kanuni Sultan Suleyman Training and Research Hospital, istanbul, Turkey \\ ${ }^{2}$ Division of Pediatric Infectious Diseases, Bezmialem Vakif University School of Medicine, Istanbul, Turkey
}

\begin{abstract}
Cite this article as: Aldemir E, Kavuncuoğlu S, Türel Ö. Epidemiology of sepsis in neonates: microbiological profile and antibiotic susceptibility. J Pediatr Inf 2019;13(4):e165-e171.
\end{abstract}

\section{Abstract}

Objective: Continuous surveillance is important to be informed on local epidemiology and cover organisms likely to cause sepsis in empirical therapy. We aimed to determine the characteristics of neonates with sepsis and etiological organisms in a single center.

Material and Methods: This retrospective study included neonates admitted at level I-III units (NICU) in Kanuni Sultan Suleyman Training and Research Hospital during a one-year period (January 1 ${ }^{\text {st }}, 2010$ to December $\left.31^{\text {st }}, 2010\right)$. The characteristics of neonates diagnosed as sepsis were compared to those without sepsis in order to determine risk factors. The distribution and resistance pattern of pathogens causing sepsis during 2010 were identified and compared with those of the previous years.

Results: Among the 4703 patients treated in our NICU, 292 (6.2\%) were diagnosed as culture proven sepsis [96 early-onset sepsis (EOS), 196 late-onset sepsis (LOS)]. Mean birth weight was $2304 \pm 1066.9 \mathrm{~g}$ (640$5250 \mathrm{~g}$ ) and mean gestational age was $36 \pm 4.2$ weeks (24-40 weeks). Preterm babies were infected four times more frequently than babies born at term [OR, $3.96(95 \% \mathrm{Cl}, 3.10-5.06, \mathrm{p}=0.001)]$. Presence of central venous catheter, ventilation support, total parenteral nutrition, and prolonged hospitalization were other risk factors for sepsis development. Mortality from EOS was higher than that from LOS $(19.8 \%$ vs. $4.1 \%, p=0.001$ ). Coagulase negative staphylococci (CoNS) were the most commonly isolated pathogens in blood cultures of term neonates. Gram-negative bacilli [Klebsiella pneumoniae (18.4\%), other GNB (27\%)] were more common in preterm babies than term neonates. Resistance to penicillin and ampicillin were high in gram-positive bacteria. Ampicillin,
Öz

Giriş: Sepsiste, lokal epidemiyolojinin bilinmesi ve ampirik tedavide etken olabilecek mikroorganizmaların kapsanması amacıyla devamlı sürveyans önemlidir. Bu çalışmada bir merkezde, sepsisli yenidoğanların özelliklerinin ve etken mikroorganizmaların belirlenmesi amaçlanmıştır.

Gereç ve Yöntemler: Bu retrospektif çalışma Kanuni Sultan Süleyman Eğitim ve Araştırma Hastanesi Yenidoğan Yoğun Bakım Ünitesi (YDYBÜ) Düzey I-III'te bir yılda (1 Ocak 2010-31 Aralık 2010) yatırılan yenidoğanları kapsamaktadır. Risk faktörlerinin belirlenebilmesi için sepsis tanısı alan yenidoğanların özellikleri sepsis olmayanlar ile karşılaştırıldı. 2010 yılında sepsise neden olan etkenlerin dağılımı ve antibiyotik dirençleri önceki yıllar ile karşılaştırıldı.

Bulgular: YDYBÜ'de tedavi edilen 4703 hastanın 292 (\%6.2)'si kültürle ispatlanmış sepsis [96 erken sepsis (EOS), 196 geç sepsis (LOS)] tanısı aldı. Ortalama doğum ağırlığı $2304 \pm 1066.9$ g (640-5250 g) ve ortalama gebelik haftası $36 \pm 4.2$ hafta ( $24-40$ hafta) idi. Enfeksiyon gelişimi preterm bebeklerde, term bebeklere kıyasla 4 kat daha fazla bulundu [OR, 3.96 (\%95 GA, 3.10-5.06; $p=0.001$ )]. Santral venöz kateter varlığı, mekanik ventilasyon desteği, total parenteral beslenme ve hastanede uzun süreli yatış diğer risk faktörleri idi. EOS'da mortalite LOS'a göre daha yüksek bulundu (\%19.8 ve \%4.1, $\mathrm{p}=0.001$ ). Term bebeklerin kan kültürlerinde en sık üreyen patojen koagülaz negatif stafilokok (KNS)'tu. Pretermlerde gram-negatif bakteriler (GNB) [Klebsiella pneumoniae \%18.4 ve diğer gram-negatifler \%27] term bebeklere göre daha sık olarak etken olmuştu. Gram-pozitif bakterilerde penisilin ve ampisilin direnci yüksekti.

\section{Correspondence Address/Yazışma Adresi \\ Özden Türel \\ Bezmialem Vakıf Üniversitesi Tıp Fakültesi, \\ Çocuk Enfeksiyon Hastalıkları Bilim Dalı, \\ İstanbul-Türkiye \\ E-mail: barisbulent98@yahoo.com}

Received: 12.12 .2018

Accepted: 19.08 .2019
(Copyright 2019 by Pediatric Infectious Diseases and Immunization Society. Available online at www.cocukenfeksiyon.org 
gentamicin, cefotaxime, and carbapenem resistances in GNB were 63\%, $36 \%, 33 \%$, and $7.5 \%$, respectively.

Conclusion: Prematurity is a major risk factor for sepsis. During the years of 1997, 2005, 2007, and 2010, CoNS remained the most frequent pathogen. The relative proportion of gram-negative bacilli is substantial in preterm babies. Carbapenem resistance in GNB is worth consideration.

Keywords: Neonate, prematurity, early-onset sepsis, late-onset sepsis, antibiotic resistance

\section{Introduction}

Sepsis constitutes the $3^{\text {rd }}$ common cause of death in neonates globally (1). World Health Organization (WHO) has reported that each year 4 million neonatal deaths occur and infections are among the leading causes of neonatal deaths (2). Knowledge on the incidence of neonatal infections is important for planning preventive and intervention strategies and for comparisons within and between countries. In developed countries, the incidence of neonatal sepsis is 1-10 over 1000 live births $(3,4)$. In developing countries, the incidence may even reach to 170 over 1000 live births when clinical sepsis cases are included $(5,6)$.

Organisms causing neonatal sepsis may vary geographically. Group B streptococcus (GBS) is the most common cause of early-onset sepsis (EOS) while coagulase-negative staphylococci (CoNS) cover over $50 \%$ of late-onset sepsis (LOS) in Western countries $(3,4)$. Limited data is available for community-acquired infections from middle and low income countries. Most EOS is due to Klebsiella spp., Escherichia coli, other gram-negative enteric bacilli; and Staphylococcus aureus, GBS, Streptococcus pneumoniae, and non-thyphoidal Salmonella spp. are among the most common pathogens in babies after seven days of age (5). A multicenter study from Turkey revealed that the most frequent microorganisms grown in blood cultures were Klebsiella spp. (seven centers), Serratia spp. (three centers), and CoNS spp. (three centers) (6).

In this study, we aimed to evaluate the incidence and risk factors of microbiologically confirmed sepsis at a sentinel neonatal unit in Istanbul, Turkey. We also compared the distribution and resistance pattern of pathogens in neonatal sepsis with those of the previous years to help assess empiric management.

\section{Materials and Methods}

\section{Setting and Subjects}

Our hospital is a referral center where 17-19 thousand babies are born annually and 4500-5000 newborns are treated at neonatology level I-III units. Both inborn and out born neonates (babies delivered in other hospitals and transferred to the study center) with clinical sepsis and at least one confir-
GNB'lerde ampisilin, gentamisin, sefotaksim ve karbapenem direnci sırasiyla $\% 63, \% 36, \% 33$ ve $\% 7.5$ bulundu.

Sonuç: Prematürite sepsis gelişimi için önemli bir risk faktörüdür. 1997, 2005, 2007 ve 2010 yıllarının tümünde KNS en sık etken olarak görülmektedir. GNB'lerin kısmi oranı preterm bebeklerde önemli yer tutmaktadır. Gram-negatif bakterilerde karbapenem direnci dikkate değerdir.

Anahtar Kelimeler: Yenidoğan, prematürite, erken sepsis, geç sepsis, antibiyotik direnci

matory blood culture were included into the study. Data were collected from January $1^{\text {st }} 2010$ to December $31^{\text {st }} 2010$. Information regarding sex, birth weight, gestational age, premature rupture of membranes (PROM), catheter insertion, ventilation support, exchange transfusion, home delivery, and duration of hospitalization were noted. Risk factors for the development of sepsis were analyzed.

\section{Definitions}

Töllner sepsis score was used to identify neonates with clinical sepsis (7). Presence of toxic appearance or high clinical index of suspicion for sepsis, a single axillary temperature reading of $>38.5^{\circ} \mathrm{C}$ or $<36.0^{\circ} \mathrm{C}$ or two consecutive temperature readings of $38.1^{\circ} \mathrm{C}$ or higher, non-palpable or weak pulse, seizures in the absence of a clear neurological cause or a full fontanel, sclerema, petechiae or cyanosis of skin or mucosae, hypotonia, bradycardia, apnea, hepatomegaly, respiratory distress, leukocytes $<5000 / \mathrm{mm}^{3}$ or $>25.000 / \mathrm{mm}^{3}$, thrombocytopenia $(<100.000 /$ $\mathrm{mm}^{3}$ ), metabolic acidosis were accepted as features of sepsis (8). Neonatal sepsis was classified as EOS if it occurred within the first week of life and LOS if it occured after the first week until the end of the neonatal period. Preterm birth referred to a delivery that occurred before 37 weeks of gestation (9). PROM referred to membrane rupture before the onset of uterine contractions (10). Preterm PROM (PPROM) was defined as PROM before $37+0$ weeks of gestation. Pneumonia was defined by using a combination of imaging, clinical and laboratory criteria (11).

\section{Microbiological Methods}

Blood samples were incubated in Bactec 9240 system (Becton Dickinson, USA) for up to 7 days. The microorganisms isolated were identified by the API 20 NE system (bioMerieux, France). Susceptibility of the organisms to antimicrobial agents was done by using (Kirby-Bauer) disk-diffusion method on Mueller-Hinton agar, according to the guidelines of Clinical Laboratory Standards Institute (CLSI).

\section{Statistical Methods}

The results were analyzed by arithmetic mean and standard deviation. SPSS 16 pocket program (IBM, Chicago, USA) was used for statistical analysis.

The study was approved by the local Ethics Board. 


\section{Results}

\section{Demographic Characteristics}

Between January2010-December2010,4703neonates were hospitalized due to various clinical problems. Of these, $292 \mathrm{pa}-$ tients (61.6\% male) were diagnosed with sepsis. Mean (SD) birth weight was 2304 (1066.9) g (range: 640-5250 g) and mean (SD) gestational age was 36 (4.2) weeks (range: $24-40$ weeks). $42.1 \%$ of the babies were delivered by normal spontaneous delivery.

\section{Associated Factors for Development of Sepsis}

Low gestational age, central venous catheter insertion, and mechanical ventilation were the most common risk factors for sepsis. $9.5 \%$ of the neonates with positive maternal genitourinary cultures developed sepsis (Table 1). Preterm premature rupture of membranes (PPROM) was reported in $8.9 \%$ of the patients with sepsis.

\section{Comparison of EOS and LOS}

There were 96 episodes of EOS and 196 episodes of LOS. Sixty-eight (70.8\%) patients with EOS and 112 (57.1\%) patients with LOS were preterm $(p<0.05)$. Pneumonia was more frequent in patients with EOS than LOS $(47.9 \%$ vs. $10 \%$, $p<$ $0.05)$. Meningitis was more common in patients with LOS than EOS ( $14 \%$ vs. $2 \%, p<0.05$ ) (Table 2 ).

\section{Etiological Organisms}

CoNS (49.8\%) were the most frequently isolated pathogens followed by Klebsiella pneumoniae (12.3\%), other gram-negative bacilli (GNB) (19\%) (e.g. Serratia spp., Pseudomonas spp., Enterobacter spp., Achromobacter xylosidans), S. aureus (9.5\%), GBS

Table 1. Risk factors for sepsis development

\begin{tabular}{|c|c|c|c|c|}
\hline Characteristic & Sepsis positive & Sepsis negative & & \\
\hline Number of neonates hospitalized & 292 & $n=4411$ & $\mathbf{p}$ & OR (95\% Cl) \\
\hline $\begin{array}{l}\text { Prematurity; } \mathrm{n}(\%) \\
\text { GA }>32 \text { weeks } \\
\text { GA }<32 \text { weeks }\end{array}$ & $\begin{array}{l}180(61.6) \\
92(31.5) \\
88(30.1)\end{array}$ & $\begin{array}{l}1273(28.9) \\
921(20.8) \\
352(7.9)\end{array}$ & $\begin{array}{l}{ }^{\mathrm{a}} 0.001^{* *} \\
{ }^{\mathrm{a}} 0.001^{* *}\end{array}$ & $\begin{array}{l}3.962(3.102-5.060) \\
2.503(1.823-3.436)\end{array}$ \\
\hline Central venous catheter; $\mathrm{n}(\%)$ & $73(25.0)$ & $308(7.0)$ & ${ }^{\mathrm{a}} 0.001^{* *}$ & $4.440(3.326-5.929)$ \\
\hline Exchange transfusion; $\mathrm{n}(\%)$ & $8(2.7)$ & $35(0.8)$ & ${ }^{b} 0.004^{* *}$ & $3.522(1.619-7.663)$ \\
\hline Prolonged hospitalization (> 14 days); n (\%) & $144(49.3)$ & $684(15.5)$ & ${ }^{\mathrm{a}} 0.001^{\neq *}$ & $5.302(4.156-6.763)$ \\
\hline PROM; n (\%) & $30(10.2)$ & $352(7.9)$ & ${ }^{\mathrm{a}} 0.165$ & $1.320(0.891-1.956)$ \\
\hline TPN; n (\%) & $165(56.5)$ & $1303(29.5)$ & $\mathrm{a} 0.001^{\neq *}$ & $3.099(2.437-3.940)$ \\
\hline Home delivery; $\mathrm{n}(\%)$ & $5(1.7)$ & $44(1.0)$ & ${ }^{b} 0.228$ & $1.729(0.680-4.394)$ \\
\hline
\end{tabular}

Table 2. Comparative characteristics of patients with early-onset sepsis (EOS) and late-onset sepsis (LOS)

\begin{tabular}{|c|c|c|c|}
\hline Characteristic & EOS $(n=96) n(\%)$ & $\operatorname{LOS}(n=196) n(\%)$ & $\mathbf{p}$ \\
\hline Prematurity & $68(70.8)$ & $112(57.1)$ & ${ }^{\mathrm{a}} 0.024^{*}$ \\
\hline Early membrane rupture & $18(18.8)$ & $12(6.1)$ & a $0.001^{* *}$ \\
\hline Mechanical ventilation & $21(21.9)$ & $57(29.1)$ & ${ }^{\mathrm{a}} 0.191$ \\
\hline Central venous catheter & $16(16.7)$ & 35 (17.9) & ${ }^{\mathrm{a}} 0.801$ \\
\hline Home septic delivery & $4(4.2)$ & $1(0.5)$ & ${ }^{\mathrm{b}} 0.042^{*}$ \\
\hline Exchange transfusion & $6(6.3)$ & $2(1.0)$ & ${ }^{\mathrm{b}} 0.017^{*}$ \\
\hline Meningitis & $2(2.1)$ & $28(14.3)$ & ${ }^{\mathrm{a}} 0.001^{* *}$ \\
\hline Pneumonia & $46(47.9)$ & $20(10.2)$ & a $0.001^{* *}$ \\
\hline Mortality & $19(19.8)$ & $8(4.1)$ & ${ }^{\mathrm{a}} 0.001^{* *}$ \\
\hline
\end{tabular}


(2.7\%), and Candida spp. [C. albicans (2\%), C. parapsilosis (1.3\%)]. Most common organisms detected in maternal cultures were GBS and $E$. coli. Preterm neonates were more frequently infected with K. pneumoniae and other GNB (18.4\% and 27\%, respectively) than term neonates (3.8\% and 1.8\%) (Figure 1,2).

\section{Antibiotic Susceptibility Pattern}

Gram-positive bacteria (GPB): GPB showed high resistance to penicillin and ampicillin ( $96 \%$ and $76.5 \%$ respectively). Vancomycin resistance was detected in $6 \%$ of GPB (all resistant isolates were Enterococcus spp.) (Figure 3).

Gram-negative bacteria (GNB): Ampicillin, gentamicin, cefotaxime, and carbapenem resistances in GNB were 63\%, $36 \%, 33 \%$, and $7.5 \%$, respectively (Figure 4 ).

\section{Mortality}

Mortality (directly or probably due to sepsis) from EOS and LOS were $19.8 \%$ and $4.1 \%$., respectively. Preterm babies showed increased mortality rate in comparison to term newborns $(12.8 \%$ vs. $3.4 \%, p<0.05)$.

\section{Discussion}

Advances in neonatology increased the survival rate of risky newborns. Nevertheless, supportive treatment beginning from delivery and invasive interventions expose the newborn to increased risk for sepsis (12-14). Most high-income settings use standardized, computerized reporting systems to track infection rates at individual institutions, and at regional and national level. In contrast, in developing countries, the

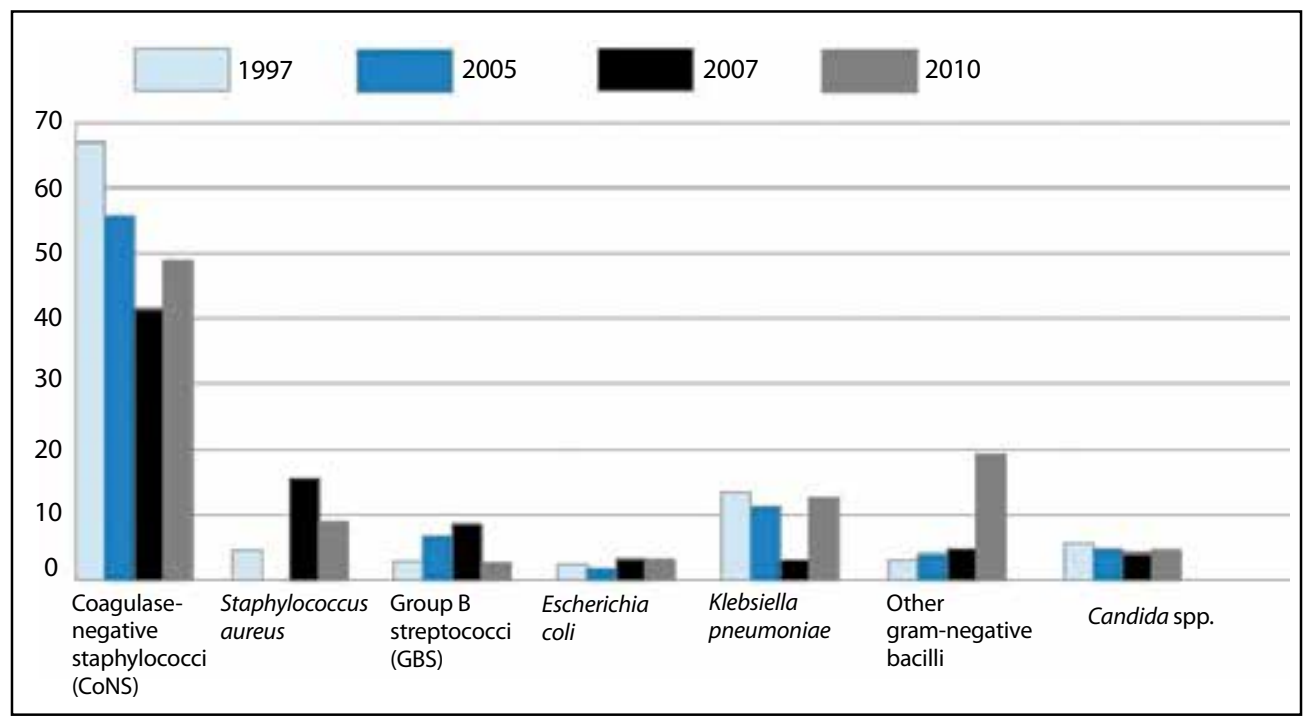

Figure 1. Microbiological profile in positive blood cultures from neonates with sepsis according to years.

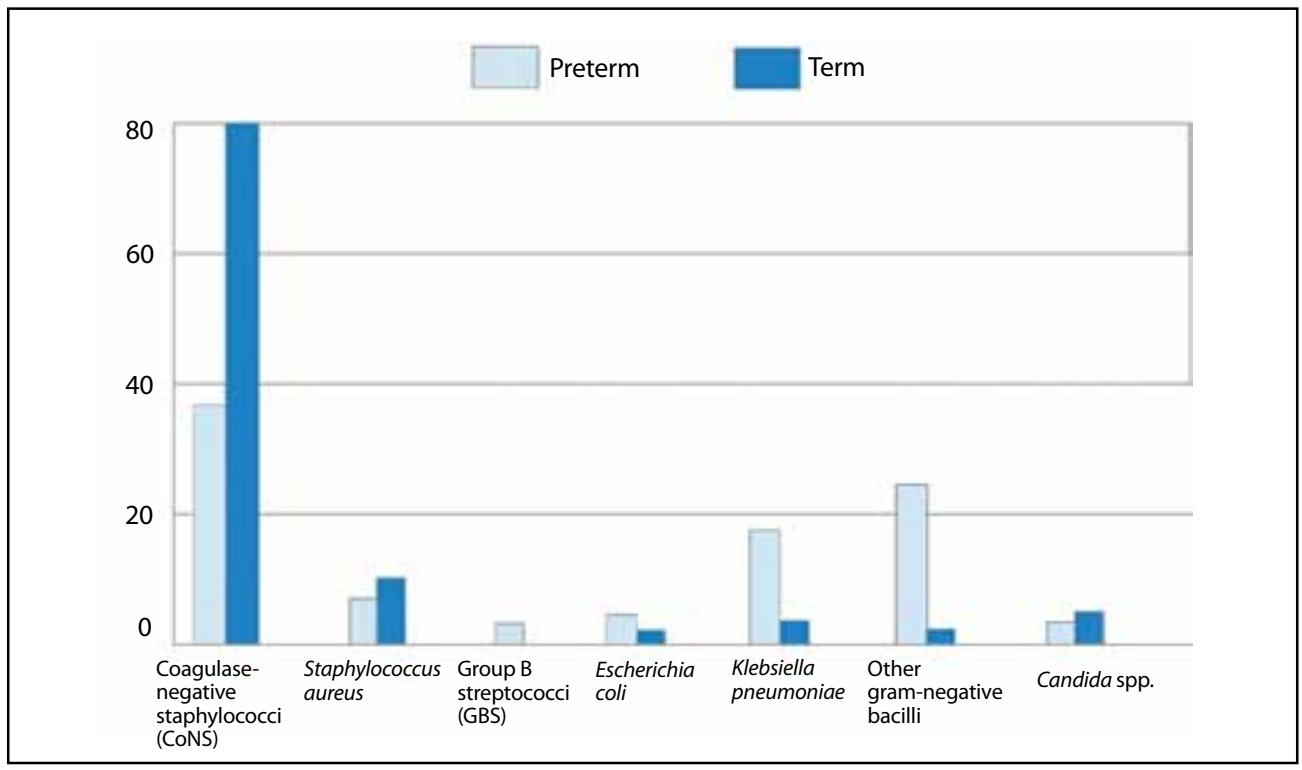

Figure 2. Comparison of pathogens causing sepsis in term and preterm neonates with sepsis. 
reliability of reported infection rate depends on factors such as definitions, case ascertainment, population selection, culturing practices, and the reliability of microbiology laboratory (15). Neonatal nosocomial infection rates are reported in the range of 6 to 9 infections/1000 patient days in high-income settings. In developing countries, these rates are much higher (15-62 infections/1000 patient days) $(16,17)$. Culture-proven sepsis frequency was $6.2 \%$ in all of the infants admitted to Kanuni Sultan Suleyman Training and Research Hospital neonatology units in 2010. Previous reports show that nosocomial sepsis incidence varies in the range of 2.1 to $17 \%$ in Turkey (6).

Lower gestational age, presence of central venous catheters, mechanical ventilation, and prolonged hospital stay were the most commonly associated factors for sepsis in this study.
Among 379 babies with gestational age less than 32 weeks, 88 (23\%) developed sepsis. In Bangladesh, home delivery (60\%) was commonly reported in neonates with sepsis. EOS and prematurity were also common and $7 \%$ of the patients had maternal infection (18). A baby with EOS is colonized with the same organism implying that colonization of the fetus' mucosal surfaces commonly precedes bacteremia. If the mother's birth canal is colonized with potentially virulent organisms (e.g. methicillin resistant S. aureus, Salmonella, Pseudomonas), a baby colonized prenatally may develop sepsis. Very recently, Esposito et al. have reported that genetic variability could play a role in sepsis in preterm neonates by influencing susceptibility to and the severity of the disease, as well as the risk of having disease due to specific pathogens (19).

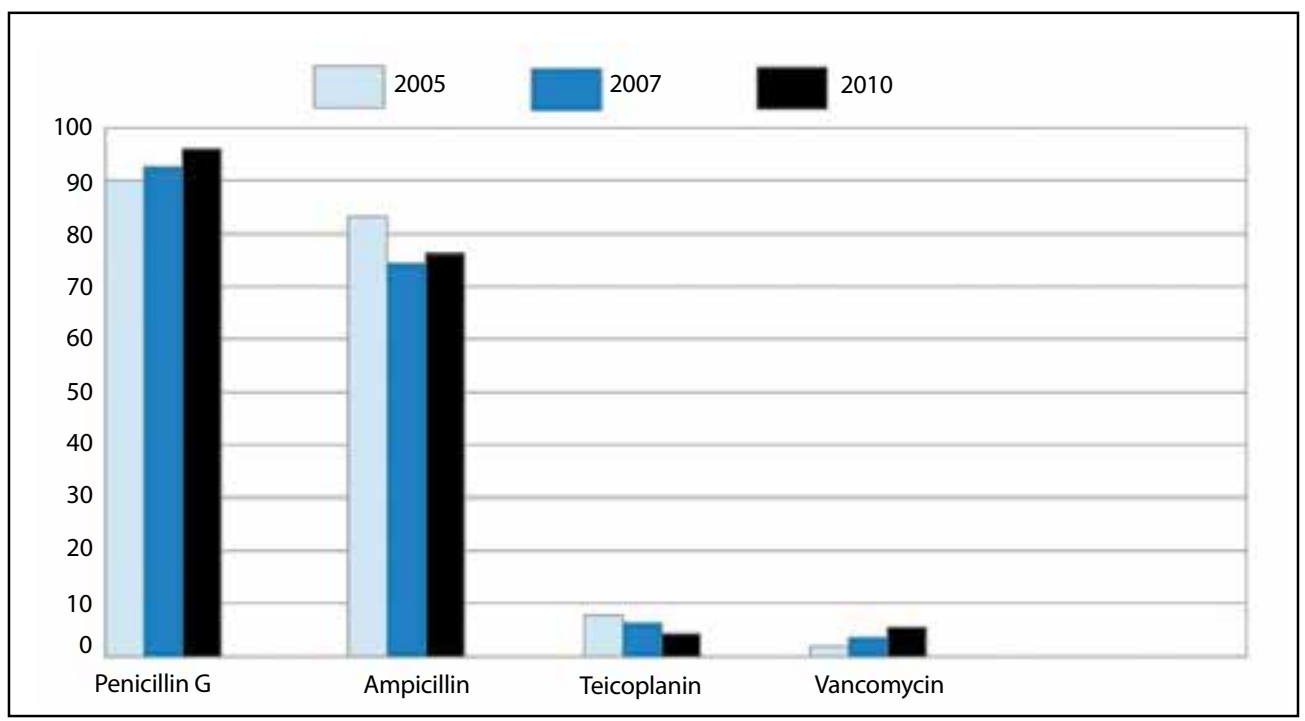

Figure 3. Comparative percentage of resistance to the tested antimicrobial agents among gram-positive isolates.

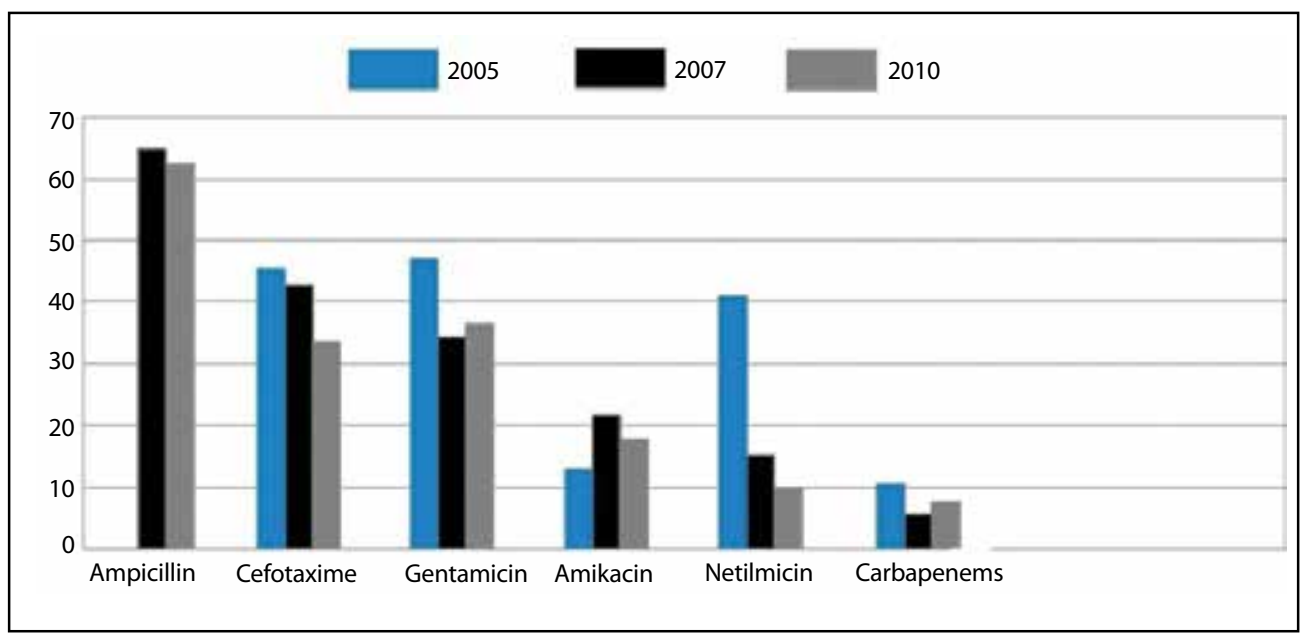

Figure 4. Comparative percentage of resistance to the tested antimicrobial agents among Gram-negative isolates. 
The causative organisms of LOS are different from those of EOS. However, a recent study from India has showed that this distinction is getting blurred (20). We identified CoNS (49.8\%) as the most common pathogens in neonatal sepsis. CoNS remained the most frequent pathogen identified in blood cultures from 1997-2010. GBS was a rare pathogen (3\%) as previously reported in Turkey (21). CoNS are known pathogens for LOS and central line associated blood stream infection (CLABSI), as well as common blood culture contaminants. The Centers for Disease Control and Prevention (CDC) defines skin contaminants (e.g. CoNS) as pathogens if the same organism is cultured from 2 or more blood cultures drawn on separate occasions and the patient has at least 1 of the following signs or symptoms (fever, chills, or hypotension) plus signs and symptoms and positive laboratory results are not related to an infection at another site (22). Freeman et al. have commented that physicians are more likely to consider a positive blood culture a true infection, irrespective of the organism, if obtained from a VLBW infant (23). Unfortunately, contamination of neonatal samples is common, and interpretation of culture results such as Staphylococcus epidermidis still relies on clinical judgment (24).

In developing countries Klebsiella spp., E. coli, and S. aureus are reported as major causes of infections in the first week of life (5). In a recent study evaluating young infants with community acquired sepsis, probable or definite pathogens have been identified in $10.6 \%$ of the newborns $0-6$ days of age (44/424) and in $10.9 \%$ of the infants $7-59$ days of age (39/358). S. aureus was the most commonly isolated species $(36 / 83$, $43.4 \%)$ followed by various species of GNB (39/83, 46.9\%; Acinetobacter spp., E. coli and Klebsiella spp. were the most common organisms) (25). We observed an increase in GNB bacilli other than Klebsiella spp. and E. coli in 2010. This increase may be partly explained by A. xylosidans outbreak in our NICU, which was described in detail in a previous report (26).

Reports of multi-resistant bacteria causing neonatal sepsis in developing countries are increasing $(5,18,27)$. Globally, gram-negative infections are increasing and drug resistance is steadily rising. In a review of 10 studies, $72 \%$ of $E$. coli was resistant to ampicillin, $78 \%$ to cotrimoxazole and $19 \%$ resistant to third generation cephalosporins (28). Klebsiella species were almost $100 \%$ resistant to ampicillin, $45 \%$ to cotrimoxazole, and $66 \%$ to third generation cephalosporins. A subsequent study from India reported that over $80 \%$ of GNB causing EOS exhibited multi-drug resistance to ampicillin, third generation cephalosporins and gentamicin indicating that these multi-resistant organisms circulate widely in the community (20). Hamer et al. reported that resistance to second and third generation cephalosporins was present in more than half of isolates causing neonatal bacteremia and $44 \%$ of the gram-negative isolates were gentamicin-resistant (25). Of note is the increasing prevalence of Enterobacteriaceae producing extended-spectrum beta-lactamases (ESBLs) in Africa. Among 717 blood stream infection episodes, gram-negative pathogens predominated (65\%), followed by gram-positives (31\%) and fungi (4\%) (29). Given the rapidly evolving resistance profiles and emerging antibiotic resistance mechanisms, our study is important to provide knowledge for Turkey. Ampicillin, gentamicin, cefotaxime, and carbapenem resistances in GNB were $63 \%, 36 \%$, $33 \%$, and $7.5 \%$ respectively. Resistances of GNB to gentamicin, cefotaxime, and carbapenems are decreased in 2010 in comparison to 2005. Judicious use of antibiotics may have led to this result.

\section{Conclusion}

CoNS-related bacteremia is the leading cause of sepsis especially among term neonates and LOS. The relative proportion of gram-negative infection is substantial in preterm babies. The observed increase in percentage of other GNB during 2010 is worth consideration and should be monitored.

Ethics Committe Approval: The study was approved by the local Ethics Board.

Informed Consent: Patient concent was obtained.

Peer-review: Externally peer-reviewed.

Author Contributions: Concept - EA, SK; Design - OT; Supervision - SK; Materials - OT; Data Collection and/or Processing - EA, OT; Analysis and/or Interpretation - OT; Literature Review - OT; Writing OT, SK; Critical Review - All of authors.

Conflict of Interest: No conflict of interest was declared by the authors.

Financial Disclosure: The authors declared that this study has received no financial support.

\section{References}

1. Black RE, Cousens S, Johnson HL, Lawn JE, Rudan I, Bassani DG, et al; Child Health Epidemiology Reference Group of WHO and UNICEF. Global, regional, and national causes of child mortality in 2008: a systematic analysis. Lancet 2010;375:1969-87. "[CrossRef]"

2. World Health Statistics 2012. Available: http://www.who.int/gho/publications/world_health_statistics/2012/en/. Accessed on December 06, 2018! [CrossRef]"

3. Vergnano S, Menson E, Kennea N, Embleton N, Russell AB, Watts T, et al. Neonatal infections in England: the NeonIN surveillance network. Arch Dis Child Fetal Neonatal Ed 2011;96:F9-14. [CrossRef]'

4. Stoll BJ, Hansen NI, Sánchez PJ, Faix RG, Poindexter BB, Van Meurs KP, et al; National Institute of Child Health and Human Development Neonatal Research Network. Early onset neonatal sepsis: the burden of group $B$ streptococcal and E. coli disease continues. Pediatrics 2011;127:817-26. "CrossRef]"

5. Zaidi AKM, Thaver D, Ali AS, Khan TA. Pathogens associated with sepsis in newborns and young infants in developing countries. Pediatr Infect Dis J 2009;28:S10-8. [CrossRef]" 
6. Turkish Neonatal Society, Nosocomial Infections Study Group. Nosocomial infections in neonatal units in Turkey: epidemiology, problems, unit policies and opinions of health care workers. Turk J Pediatr 2010;2:50-7.

7. Töllner U. Early diagnosis of septicemia in the newborn. Clinical studies and sepsis score. Eur J Pediatr 1982;138:331-7. [CrossRef]

8. Rosenberg RE, Ahmed AS, Saha SK, Chowdhury MA, Ahmed S, Law PA, et al. Nosocomial sepsis risk score for preterm infants in low-resource settings. J Trop Pediatr 2010;56:82-9!'[CrossRef]',

9. Ballard JL, Khoury JC, Weding K, Wang L, Eilers-Walsman BL, Lipp R. New Ballard score, expanded to incude extremely premature infants. $J$ Pediatr 1991; 119:541-54. [CrossRef],

10. Herbst $A$, Källén K. Time between membrane rupture and septicemia, in term neonates. Obstet Gynecol 2007;110:612-8. [CrossRef].

11. CDC/NHSN Surveillance Definitions for Specific Types of Infections. Available: $\quad$ http://www.cdc.gov/nhsn/PDFs/pscManual/17pscNos/nfDef_current.pdf. Accessed on 27th July 2015. [CrossRef].

12. Schuchat A, Zywicki SS, Dinsmoor MJ. Risk factors and opportunites for prevention of early-onset neonatal sepsis, a multicenter case-control study. Pediatrics 2000;105:21-6. [CrossRef]

13. Ohlin A. What is neonatal sepsis? Acta Pediatr 2011;100:7-8.'[CrossRef]']

14. Klinger G, Levy I, Sirota L, Boyko V, Reichman B, Lerner-Geva L; Israel Neonatal Network. Epidemiology and risk factors for early onset sepsis among very-low-birthweight infants. Am J Obstet Gynecol 2009;201:38. e1-6. [CrossRef]"

15. Thaver D, Zaidi AK. Burden of neonatal infections in developing countries: a review of evidence from community-based studies. Pediatr Infect Dis J 2009;28:S3-9."[CrossRef]

16. Posfay-Barbe KM, Pittet D. Health careassociated_infections in neonates. Curr Opin Infect Dis 2008;21:228-34."[CrossRef]

17. Allegranzi B, Bagheri Nejad S, Combescure C, Graafmans W, Attar H, Donaldson $L$, et al. Burden of endemic health-care associated infection in developing countries: systematic review and meta-analysis. Lancet 2011;377:228-41."[CrossRef]"

18. Ahmed AS, Chowdhury MA, Hoque M, Darmstadt GL. Clinical and bacteriological profile of neonatal septicemia in a tertiary level pediatric hospital in Bangladesh. Indian Pediatr 2002;39:1034-9.
19. Esposito S, Zampiero A, Pugni L, Tabano S, Pelucchi C, Ghirardi B, et al. Genetic polymorphisms and sepsis in premature neonates. PLoS One 2014;9:e101248.

20. Viswanathan R, Singh AK, Basu S, Chatterjee S, Sardar S, Isaacs D. Multidrug resistant gram negative bacilli causing early neonatal sepsis in India. Arch Dis Child Fetal Neonatal Ed 2012;97:F182-7.

21. Gökalp A, Oğuz A, Bakici Z, Gültekin A, ToksoyH, Gürel M, et al. Neonatal group $B$ streptococcal colonization and maternal urogenital or anorectal carriage. Turk J Pediatr 1988;30:17-23.

22. Horan TC, Andrus M, Dudeck MA. CDC/NHSN surveillance definition of health care-associated infection and criteria for specific types of infections in the acute care setting. Am J Infect Control 2008;36:309-32. [CrossRef],

23. Freeman J, Platt R, Sidebottom DG, Leclair JM, Epstein MF, Goldmann $D A$. Coagulase-negative staphylococcal bacteremia in the changing neonatal intensive care unit population. Is there an epidemic? JAMA 1987;258:2548-52. [CrossRef $]_{1}$

24. Molyneux E, Gest A. Neonatal sepsis: an old issue needing new answers. Lancet Infect Dis 2015; 15:503-5. [CrossRef].

25. Hamer DH, Darmstadt GL, Carlin JB, Zaidi AK, Yeboah-Antwi K, Saha SK, et al; Young Infants Clinical Signs Study Group. Etiology of bacteremia in young infants in six countries. Pediatr Infect Dis J 2015;34:e1-8. [CrossRef],

26. Turel O, Kavuncuoglu S, Hosaf E, Ozbek S, Aldemir E, Uygur T, et al. Bacteremia due to Achromobacter xylosoxidans in neonates: clinical features and outcome. Braz J Infect Dis 2013;7:450-4. [C [CrossRef]

27. Jyothi P, Basavaraj MC, Basavaraj PV. Bacteriological profile of neonatal septicemia and antibiotic susceptibility pattern of the isolates. J Nat Sci Biol Med 2014;4:306-9. [CrossRef].

28. Lubell Y, Ashley EA, Turner C, Turner P, White NJ. Susceptibility of community-acquired pathogens to antibiotics in Africa and Asia in neonates--an alarmingly short review. Trop Med Int Health 2011;16:145-51. [CrossRef]"

29. Dramowski A, Madide A, Bekker A. Neonatal nosocomial bloodstream infections at a referral hospital in a middle-income country: burden, pathogens, antimicrobial resistance and mortality. Paediatr Int Child Health 2015;35:265-72. [CrossRef]" 